УДК 37.018.32(470.22)”192/193”(045)

\title{
А.В. Чебаковская
}

\section{ПРОДОВОЛЬСТВЕННОЕ ОБЕСПЕЧЕНИЕ ВОСПИТАННИКОВ ДЕТСКИХ ДОМОВ КАРЕЛИИ В 1920-Х - ПЕРВОЙ ПОЛОВИНЕ 1930-Х ГОДОВ ${ }^{1}$}

В статье рассматривается вопрос обеспечения продовольственным пайком воспитанников детских домов Карелии в 1920-х — первой половине 1930-х гг. Проблема детского питания отражена и в официальных документах Наркомата просвещения РСФСР, и в работах советских врачей рекомендательного характера. Инструкторы и доктора наркоматов просвещения и здравоохранения РСФСР занимались различными вопросами питания воспитанников детдомов: разработкой норм суточного пищевого пайка, определением необходимого в нём количества полезных элементов, составлением правильного меню для детей и др. Цель статьи - сравнить нормативы и реальное снабжение продовольствием воспитанников детдомов в 1920-х — первой половине 1930-х гг. При написании статьи использовались материалы и документы Государственного архива Российской Федерации и Национального архива Республики Карелия, позволившие увидеть не только утверждённые Отделом охраны здоровья Наркомата просвещения РСФСР нормы питания, но и реальное обеспечение детских учреждений пищевым пайком на местах. В исследуемый период существовал комплекс проблем обеспечения питанием воспитанников детдомов, полного решения которых не было достигнуто.

Ключевые слова: охрана детства, детский дом, детское питание, продовольственный паёк, Карелия.

DOI: $10.35634 / 2412-9534-2020-30-1-153-164$

Нуждающиеся в послереволюционной России дети находились на обеспечении государства, ставившего для себя в начале 1920 -х гг. как одну из главных задач в социальной сфере - заботу о ребёнке. Самыми незащищёнными среди детей были дети-сироты, дети из семей, попавших в нужду, беспризорные дети. Именно они становились воспитанниками детдомов. В таких учреждениях социальной защиты дети были на полном обеспечении государства. Питание, одежда, обувь, предметы личной гигиены, книги и проч. - всё было подчинено нормативам, установленным центральными государственными органами. Однако на местах эти нормы крайне редко обеспечивались.

В 1921 г. Комиссия по улучшению жизни детей (Деткомиссия) при ВЦИК, являясь главным органом в ведении всех вопросов обеспечения детей и их интересов, наметила основную задачу в своей деятельности: «спасение детей», в связи с чем вопрос продовольственного снабжения был главным. Анализ норм продовольственных пайков и отчётов детских учреждений позволил увидеть разрыв между утверждённым и реальным обеспечением.

Первые исследования, посвящённые детскому питанию, появились ещё в 1920-х - 1930-х гг., когда врачи, используя зарубежные наработки и собственные практики работы в детских учреждениях, старались определить для них принципы правильного питания. В своих трудах они показывали отличие детского питания от взрослого, выделяли ценные продукты питания, описывая важность каждого пищевого элемента, обосновывали нормы, суточные продовольственные пайки и меню для детей разных возрастов $[6 ; 10 ; 13 ; 14 ; 23]$. Исследователей интересовали вопросы влияния питания на заболеваемость и смертность детей, на их физическое и умственное развитие, применения суррогатов и замены одних продуктов другими, распределения пищевого пайка в течение суток и др. [7-9; $15 ; 19 ; 25 ; 30]$. В помощь родителям и сотрудникам детских учреждений доктора составляли меню и рецепты для разнообразия ежедневного питания [17; 24; 31]. Однако, как они сами отмечали, их «голос, к сожалению, имел лишь совещательный характер» в организации детского питания [11, с. 1]. Представляет интерес исследование 1935 г. сотрудников Ленинградского научно-исследовательского института общественного питания по изучению физического состояния ребёнка при разной пищевой нагрузке [22].

Рассматривая современное историографическое освещение вопроса, стоит заметить, что в основном исследователи анализируют общее состояние детдомов в определённых регионах страны $[3-5 ; 16 ; 18 ; 21 ; 29]$, не останавливаясь подробно на продовольственном обеспечении воспитанников учреждений и чаще всего оставляя без внимания существовавшие нормативы. Авторы описывают

\footnotetext{
${ }^{1}$ Финансовое обеспечение исследования осуществлялось из средств федерального бюджета на выполнение государственного задания КарНЦ РАН (АААА-А18-118030190093-9).
} 
материально-бытовое положение детдомов и указывают, что питание детей было самой острой проблемой. Н. В. Рябинина обращается к рассмотрению вопросов, связанных с ликвидацией беспризорности и преступности в 1920-е гг. по материалам губерний Верхнего Поволжья [26]. Автор пишет о ситуации в регионе, которая была такой же, как и во всей стране. В ряде городов Рыбинской губернии практиковалось так наз. «узаконенное попрошайничество», когда голодные воспитанники ходили по дворам и просили продукты у населения, а результаты сбора поступали в общий котёл.

Шире данный вопрос рассмотрен в статье А. А. Карасёвой [16], которая обратилась к проблеме финансирования и материального снабжения детдомов в 1930-е гг. Автор затрагивает показатель «нормы стоимости» воспитанника, фиксирует затрачиваемые средства на детей в учреждениях различного типа с 1933 по 1937 год и отмечает, что в данный период удалось существенно увеличить нормы по содержанию детдомовцев, несмотря на переживаемые страной трудности.

Отдельным вопросом, который оказался в поле зрения исследователей, стало развитие подсобного хозяйства по выращиванию сельскохозяйственной продукции, в первую очередь - овощей, как способ продовольственного обеспечения воспитанников. Например, С. Е. Лупаренко [20] анализирует деятельность детских городков в системе работы с беспризорными детьми в СССР и приводит сведения по выращенной и собранной воспитанниками продукции. Следует обратить внимание на работу Т. М. Смирновой [27], в которой исследователь рассматривает соответствие между провозглашённой государством политикой в деле охраны материнства и детства и повседневными реалиями того времени. В своём труде Т. М. Смирнова останавливается на финансировании детских учреждений и на условиях жизни в них детей и приводит в приложении ценные статистические данные по губерниям о численности детдомовцев и их обеспеченности продовольствием. Однако Карелия не фигурирует в названных исследованиях.

Таким образом, исследователи дали характеристику состояния детских учреждений ряда таких регионов и городов, как Астраханский край и регионы Верхнего Поволжья, Башкирия, Москва, Саратов, Севастополь, Ярославль и др. Авторы, как правило, работают в русле новой локальной истории. Используя историко-сравнительный метод, исследователи сопоставляют, например, изменения, происходившие в материальных, финансовых, воспитательных, кадровых и других сферах работы детских учреждений на уровне региона и страны, что позволяет выявить общее и особенное, определить закономерности и различия сравниваемых явлений. Некоторые используют междисциплинарный подход, позволяющий рассматривать проблемы детских учреждений в поле не только изучения истории, но и педагогики, психологии, медицины и других наук.

Цель данной статьи - сравнить нормативы и реальное снабжение продовольствием воспитанников детдомов Карелии в 1920-х — первой половине 1930-х гг.

При написании статьи использовались материалы и документы Государственного архива Российской Федерации, а именно: фонд Деткомиссии при ВЦИК. Также были проанализированы источники, хранящиеся в Национальном архиве Республики Карелия, в основном, фонды Наркомпроса АКССР (Народного Комиссариата просвещения Автономной Карельской Советской Социалистической Республики) и Деткомиссии при Центрисполкоме, в которых наряду с комплексом законодательных и директивно-распорядительных материалов содержатся дела в виде отчётов с мест, материалы обследования детских учреждений, переписка с местными уполномоченными и отделами народного образования.

В начале 1920-х гг. не было установлено единых общегосударственных норм продовольственного пайка. Для каждой губернии в зависимости от её местных условий были разработаны свои суточные нормы пищевого обеспечения. Все расчёты калорийности детского пайка, необходимого количества жиров, белков и других элементов носили теоретический характер, оставаясь лишь абстрактными рекомендациями по здоровому питанию детей. В 1920-х гг. началась исследовательская работа советских врачей по определению главных требований к правильному питанию ребёнка в семье и в детских учреждениях. В книге проф. Н. К. Игнатова в 1922 г. говорилось о том, что «пища детей всякого возраста должна содержать все нужные для жизни и роста ребёнка вещества, она должна быть легко усвояема, вкусна и доставляться в нужном количестве» $[14$, с. 7]. Ориентация детских учреждений на простые принципы организации питания детей могла помочь в данном остром вопросе.

В некоторых губерниях нормы питания детей дифференцировались по возрасту, а в редких случаях — и по состоянию здоровья. Так, в Москве и Московской губернии пайки были разделены на три категории: для детей от 3 до 8 лет, от 8 до 16 лет, а также для «дефективных» детей и детей, находя- 
щихся на санаторном лечении [27, с. 215]. Врачи заявляли о необходимости дифференциации питания детей по возрасту. Если между ранним и старшим возрастом в работах врачей существовало чёткое деление суточных продовольственных пайков, иногда даже более подробная дифференциация (от 0 до 2 лет, от 2 до 4 лет, от 4 до 5 лет, от 5 до 8 лет, от 8 до 16 лет), то в вопросе отличия детского и взрослого пайка мнение исследователей расходилось. Доктор Н. К. Игнатов считал, что питание здоровых детей после 7 лет не должно отличаться от пищи взрослого человека [14, с. 110], а В. Б. Киселёва определяла возраст, когда детям можно кушать вместе со взрослыми - после 3-х лет, однако в этом случае желательно было иметь для них специальную посуду небольших размеров $[17$, с. 2]. Врач Л. Г. Исраэлян отмечал необходимость отдельного питания ребёнка от взрослого стола $[15$, с. 39], а проф. Л. Лангштейн утверждал, что питание детей школьного возраста должно соответствовать питанию взрослых и по своему составу, и по расписанию [19, с. 54].

В 1920 г. Отдел охраны здоровья Наркомпроса РСФСР разослал на места таблицы для детских учреждений: «Суточная норма питания», «Замена одних продуктов другими по их питательной (калорийной) ценности» [2, ф. p-2, оп. 1, д. 479, л. 8]. В них определялось не только необходимое количество продуктов для детей возраста от 3 до 15 лет, но и желательные продукты с их калорийной ценностью. Для воспитанника детского учреждения дошкольного возраста (от 3 до 8 лет) суточная калорийность продуктов по нормативам составляла 1860 ккал, для школьного возраста (от 8 до 15 лет) - 2277 ккал. Сотрудники отдела охраны здоровья подробно останавливались на количестве необходимых элементов питания для детей в зависимости от возраста, а также определяли возможные замены продуктов (с содержанием белков, жиров и углеводов) в случае их отсутствия. Данные сведения не просто служили рекомендациями по питанию воспитанников, но определялись как обязательные нормы для всех учреждений Наркомпроса РСФСР.

Составленные врачами в начале 1920-х гг. рекомендательные нормы для суточного пайка детей отличались от нормативов, установленных Отделом охраны здоровья Наркомпроса РСФСР. В выработанных докторами нормативах заметно большее число наименований пищевого пайка, нормы и калории понижены в количественном отношении, что связано с научным обоснованием каждого продукта в рационе детей. Совпадали лишь объёмы потребления сливочного масла и яиц. Количество хлеба и мяса (или рыбы) в составленных врачами рекомендательных нормах питания было меньше в 2-3 раза, что объяснялось их восполнением другими продуктами. Доктор Л. Г. Исраэлян считал, что в детском питании нужно ограничить или полностью избегать потребления мяса или мясных продуктов, а кондитерские изделия полностью вычеркнуть из пищевого рациона [15, с. 39]. Многие врачи отмечали необходимость разнообразить питание детей в целях «возбуждения и поддержания аппетита» [15, с. 51], покрытия потребностей ребёнка во всех нужных пищевых веществах, уменьшения случаев заболеваемости. Считали, что детям приедались «такие кушанья как пшённая каша, гороховый кисель, снетки» [14, с. 111], а самыми ценными продуктами были молоко, яйца, сливочное масло, крупа, хлеб, сахар, свежие овощи и фрукты.

Имеющиеся статистические данные по губерниям о введённых нормах обеспеченности воспитанников детдомов продовольствием, предметами повседневного пользования и медицинским обслуживанием в 1921 г. позволяют не просто увидеть общую картину нормативов по питанию, но и сравнить эти данные с требованиями Отдела охраны здоровья Наркомпроса РСФСР и рекомендациями врачей.

Суточный паёк в детских учреждениях закрытого типа в 1921 г. включал по утверждённым нормам, в основном, следующие продукты: мясо, рыбу, хлеб или муку, пшено или пшеницу, картофель, сахар, соль. Крайне редко в нормативных списках 1920-х гг. можно встретить упоминание масла и других жиров, яблок, капусты, лука, птицы, яиц, молока, кофе, клюквы, сухофруктов, приправ.

Установленные нормативные объёмы потребления продуктов питания варьировались по регионам. Однако в отдельных губерниях были некоторые совпадения в обеспечении воспитанника детдома продовольствием. Так, в 1921 г. во Владимирской, Воронежской и Московской губерниях в день ребёнку полагалось 453 г (1 фунт) $)^{1}$ хлеба, в Ивано-Вознесенской, Калужской, Псковской и Самарской губерниях данная цифра была понижена до 340 г (0,75 фунта), а в Царицынской губернии - до 272 г $(0,6$ фунта) хлеба [27, с. 350-358]. Мука значилась не во всех нормативных списках, однако если присутствовала, то либо как замена хлеба, либо как отдельный продукт (от 25,5 до 340 2). Норма мяса или рыбы варьировалась от 8,5 до 179 г (2 до 42 золотников). Самые высокие нормы потребления

\footnotetext{
${ }^{1}$ Для облегчения восприятия единицы измерения массы (золотник и фунт) были переведены автором в граммы.
} 
этих продуктов были установлены в Псковской губернии, самые низкие - во Владимирской. Крупа была представлена в основном в виде пшеницы и пшена и фиксировалась от 30 до 115 г (7 до 27 золотников), картофель - от 1 до 272 г (0,25 до 64 золотников). Сахар и соль чаще всего составляли 612 г (1,5-3 золотника), однако в Московской и Царицынской губерниях норма сахара была зафиксирована весом в 28 г (6,7 золотника) [27, с. 350-358].

Как видно, данные по губерниям не фиксировали разделения питания детей по возрасту, возможно, в виду отсутствия такой дифференциации на местах. Представленные нормы не целиком сходятся с выработанными нормативами Отдела охраны здоровья Наркомпроса РСФСР и рекомендациями врачей. В отношении хлеба, крупы, мяса можно говорить о совпадении средних показателей, тогда как объёмы потребления муки, картофеля, сахара, наоборот, отличаются от принятых нормативов.

Исследователь Т. М. Смирнова вычислила, что в начале 1920-х гг. в среднем по стране воспитанник детдома в сутки получал 200-300 г хлеба, около 100 г мяса или рыбы, 100 г крупы, 300-400 г картофеля, по 12 г сахара и соли. Крайне редко в продовольственный паёк включали 20 штук яиц в месяц, 1 стакан молока в день и по 200 г овощей и сухофруктов [27, с. 217]. Однако чаще всего хлебный паёк составлял чуть более 200 г (0,5 фунта), а жиры, мясо, овощи, молоко, яйца и сахар вовсе отсутствовали. Круп было мало, и они не отличались разнообразием, а иногда даже были непригодны для питания, поскольку в детдома нередко попадали испорченные из-за неправильной транспортировки или недоброкачественные продукты [16, с. 177]. В детдомах отмечались частые случаи отравления детей из-за некачественной пищи.

В начале 1920-х гг. фактический суточный паёк не соответствовал норме полностью, что было связано, в частности, и с большим числом детей-сирот. Для того чтобы всех детдомовцев обеспечить продуктами питания, приходилось дробить пайки, которые и так являлись недостаточными. Эти пайки удовлетворяли едва ли 50 \% всех воспитанников детских учреждений [29, с. 43].

Перечень продуктов питания детей, находящихся на попечении государства в Карелии, в целом не отличался от других губерний страны. Однако выработанные центром нормативы не совпадали с установленными здесь нормами.

В 1920 г. в Карелии были определены нормы продовольственного пайка на 2 месяца для детей в возрасте от 3 до 8 лет и от 8 до 16 лет, набор продуктов был одинаковым для той и другой возрастной группы, только объём муки для воспитанников школьного возраста был больше на 1700 г (мука: от 3 до 8 лет - 5100 г, от 8 до 16 лет - 6800 г) [2, ф. p-2, оп. 1, д. 689, л. 26]. Характерно, что в нормативы для школьников было включено 226 г (0,5 фунтов) мыла, чего не предусматривалось для младших детей.

Указанные выше нормы позволили рассчитать примерное количество продуктов на одного воспитанника в возрасте от 3 до 8 лет и от 8 до 16 лет на сутки (табл. 1) ${ }^{1}$ :

Таблица 1

Нормы продовольственного пайка на воспитанника детдома в сутки в Карелии, 1920 г.

\begin{tabular}{|c|c|c|}
\hline Наименование продуктов & \multicolumn{2}{|c|}{ Количество (в граммах) } \\
\hline Мука & 83 (3-8 лет) & 111 (8-16 лет) \\
\hline Чечевица & \multicolumn{2}{|c|}{27} \\
\hline Картофельная мука & \multicolumn{2}{|c|}{3,7} \\
\hline Разные корешки & \multicolumn{2}{|c|}{33} \\
\hline Мясо & \multicolumn{2}{|c|}{27} \\
\hline Картофель & \multicolumn{2}{|c|}{111} \\
\hline Масло & \multicolumn{2}{|c|}{7} \\
\hline Caxap & \multicolumn{2}{|c|}{7} \\
\hline Соль & \multicolumn{2}{|c|}{3,5} \\
\hline Яйца & \multicolumn{2}{|c|}{2 шт. в мес. } \\
\hline Чай & \multicolumn{2}{|c|}{0,2} \\
\hline
\end{tabular}

\footnotetext{
${ }^{1}$ В целях обеспечения сопоставимости данных, нормы питания были пересчитаны автором на суточный паёк одного воспитанника. Стоит отметить, что в материалах по учёту норм продовольственного обеспечения детских учреждений не имелось единообразия. Данные представлялись в различных весовых измерениях, и отсутствовал чёткий список постоянных продуктов.
} 
В нормах питания детей в Карелии присутствовала дифференциация по возрасту, поэтому возможно сравнение с суточным продовольственным пайком, разработанным Отделом охраны здоровья Наркомпроса РСФСР. Оно показывает, что нормативы продуктов для детей в Карелии в 1920 г. были намного ниже. Например, мяса предусматривалось в 3-4 раза меньше, картофеля - в 2-4 раза, корнеплодов - в 6 раз, масла и сахара - в 3,5 раза меньше. По нормам продовольственного пайка воспитаннику детдома в Карелии крайне редко полагалось выдавать яйца (вместо установленной ежедневной выдачи 1 яйца - 2 яйца в месяц), а хлеба и крупы вовсе не предусматривалось. Отсутствие хлеба в перечне норм продуктов связано с тем, что хлебные изделия готовили прямо в детдомах. В связи с этим, заметно повышение нормы муки в Карелии для каждой возрастной группы более, чем в два раза, однако как замены хлеба её не хватало для полноценного суточного питания воспитанника детдома. Разработанные нормативы Отдела охраны здоровья требовали поставки хлеба в детские учреждения в готовом виде. Нормы детского питания в Карелии были сильно занижены по отношению к выработанным требованиям, в них отсутствовало также определение калорийности продуктов. Всё это демонстрирует отход на местах от установленных нормативов Отделом охраны здоровья Наркомпроса РСФСР, что было обусловлено (в т. ч.) оценкой конкретных условий каждого региона.

В 1923 г. внесли изменения в нормы детского пайка в Карелии, а именно в объёмы потребления мяса, крупы и молока. В месяц воспитаннику детдома полагалось уже 4,5 к2 (10 фунтов) мяса, 6,8 кг (15 фунтов) крупы и одна бутылка молока в день [2, ф. p-630, оп. 1, д. 57, л. 312]. Это означало, что в сутки ребёнок должен был получать ко всем обозначенным в 1920 г. продуктам 150 г мяса и 220 г крупы. Как видим, за три года заметен рост некоторых нормативов в Карелии, которые превысили нормы Отдела охраны здоровья Наркомпроса РСФСР.

Отчёты детских учреждений Карелии позволяют увидеть и другую сторону изучаемого вопроca, а именно: понять, насколько реальная ситуация соответствовала установленным нормам. В ходе анализа отчётов был обнаружен следующий диапазон колебаний: количество выдаваемого хлеба варьировалось в Карелии в течение 1920-х гг. и составляло 340-453 г (0,75-1 фунт). Например, воспитанники Девятинского детдома в 1919 г. получали $3 / 4$ фунта хлеба в день, что составляло примерно 340 г [2, ф. p-2, оп. 1, д. 469, л. 3]. В Шестовском детдоме в 1920 г. количество выдаваемого хлеба зависело от возраста и времени года: для детей дошкольного возраста выдавалось 340 г (0,75 фунта), для детей школьного возраста - 453 г (1 фунт) [2, ф. p-2, оп. 1, д. 469, л. 35]. С наступлением зимы в этом детдоме уравнивались объёмы выдачи хлеба для детей и дошкольного, и школьного возрастов до 1 фунта для всех воспитанников. В основном хлеб пёкся из ржаной муки, но иногда добавлялась пшеничная и просяная (пшенная) мука.

В 1922 г. в Карелии были получены отчёты детских учреждений, по которым сотрудники Наркомпроса высчитали за три месяца среднюю норму питания в сутки на одного воспитанника: хлеб 453 г (1 фунт), мясо или рыба - 90 г ( 0,2 фунта), крупа - 90 г (0,2 фунта), масло и соль - 21 г (5 золотников), сахар - 8,5 г (2 золотника) [2, ф. p-630, оп. 1, д. 52, л. 6]. Данные объёмы потребления продуктов были средними по стране и находились примерно на уровне установленных нормативов Отдела охраны здоровья Наркомпроса РСФСР.

По установленным нормам и рекомендациям врачей в пайке воспитанника детдома обязательно должны были быть молоко и яйцо, однако увидеть их в рационе детей можно было крайне редко. Это подтверждали осмотры инспекторами Наркомпроса АКССР детдомов и отчёты заведующих: «молоко не выдаётся, масло скоромного нет, постное масло переносится плохо, ибо все дети рахитики» [2, ф. p-630, оп. 1 , д. 43, л. 47]. Дети постоянно испытывали голод; на почве недостаточного и неправильного питания появлялись болезни: малокровие, хронические расстройства пищеварения, истощение, «чесотка и также от малого молочного питания - чахотка» $[2, \phi$. p-2, оп. 1 , д. 689, л. 19]. Недостаток овощей приводил к появлению у детей цинги. Врач М. Г. Данилевич выделял следующие причины появления данного заболевания у воспитанников детских учреждений: однообразное питание, отсутствие овощей, неправильное откармливание детей после голодания, плохая наследственность или наличие хронических инфекций [8, с. 16-19]. Доктор считал, что именно из-за перенесённого в прошлом голодания и неправильного питания, дети в начале 1920-х гг. были предрасположены к инфекционным заболеваниям, страдали «авитаминозностью, отёками и неустойчивостью в отношении неблагоприятных внешних жизненных влияний» [8, с. 28].

В 1925 г. в докладе Наркомпроса АКССР был обозначен месячный набор пайка по детдомам и интернатам $[2$, ф. р-630, оп. 1 , д. 98 , л. 26], согласно которому суточный объём продуктов выглядел следующим образом (табл. 2): 
Суточный продовольственный паек воспитанника детдома в Карелии, 1925 г.

\begin{tabular}{|c|c|c|}
\hline Набор продуктов & $\begin{array}{c}\text { Количество 1923/1924 } \\
\text { (в граммах) }\end{array}$ & $\begin{array}{c}\text { Количество 1924/1925 } \\
\text { (в граммах) }\end{array}$ \\
\hline Мука ржаная & 453 & 546 \\
\hline Мука белая & 151 & 151 \\
\hline Крупа & 120 & 120 \\
\hline Мясо & 120 & 120 \\
\hline Масло & 24 & 30,2 \\
\hline Сахар & 22 & 30,2 \\
\hline Овощи & 302 & 302 \\
\hline Чай & 0,9 & 0,9 \\
\hline Кофе & 1,8 & 1,8 \\
\hline Соль & 22,6 & 22,6 \\
\hline Компот (сухофрукты) & 15,1 & 15,1 \\
\hline Картофельная мука & 7,5 & 7,5 \\
\hline
\end{tabular}

Данная отчётность позволяет увидеть изменившиеся нормативы суточного пайка, а также появление новых продуктов (кофе, сухофрукты, деление муки на ржаную и белую), увеличение некоторых элементов питания на протяжении 1923-1925 гг., например, рост ржаной муки, масла и сахара. В отчёте отмечалось, что, «в общем, питание было поставлено удовлетворительно, только несколько однообразно, что было неизбежно при закупке для всех детдомов продуктов Наркомпросом» [2, ф. p-630, оп. 1, д. 98, л. 26]. В 1925-1926 гг. некоторым детдомам было предоставлено право самостоятельно распоряжаться кредитами, что открывало возможность разнообразить питание воспитанников.

Во второй половине 1920-х гг. ситуация с питанием в Карелии немного изменилась благодаря развитию подсобных хозяйств, состоявших, в основном, из огородного участка и домашнего скота. Так, в Пудожском детдоме огородно-полевое дело было поставлено на хороший уровень: «огород мог служить показательным и стоял намного выше школы крестьянской молодёжи» - так характеризовал положение дел проверяющий детское учреждение инспектор Наркомпроса АКССР [2, ф. p-726, оп. 1, д. 17, л. 22]. Заведующий учреждением отмечал, что «если бы не свои коровы детдома и не огороды, овощей которых хватает чуть ли не на целый год, детишки голодали бы» [2, ф. p-2, оп. 1, д. 901, л. 6]. Огород при детском учреждении был жизненной необходимостью, хотя и в этом вопросе возникали свои трудности. Подсобное хозяйство содержалось лишь за счёт самого детского учреждения. В 1924 г. воспитанниками детдомов Петрозаводска было засеяно 4970 кг (305 пудов) картофеля и до 5000 ростков капусты и брюквы, скошено около 8150 кг (500 пудов) сена [2, ф. р-630, оп. 1, д. 96, л. 66].

В первой половине 1930-х гг. суточные нормы продовольственного пайка в детдомах Наркомпроса РСФСР были скорректированы [1, ф. p-5207, оп. 3, д. 19, л. 19]. По сравнению с разработанной в 1920 г. суточной нормой питания воспитанников в нормативах 1932 г. было увеличено количество хлеба, сахара и молока, понижены объёмы потребления муки, мяса, крупы, яиц, масла; в рацион была включена рыба.

Отчёты инспекторов Наркомпроса АКССР и детдомов первой половины 1930-х гг. демонстрировали реальную обстановку в вопросе обеспеченности продовольствием. Например, воспитанники первого детдома Петрозаводска в 1933 г. просили проверяющего инспектора Наркомпроса АКССР увеличить для них количество хлеба на день с 450 г до 600, или дополнительно выдавать «булки на завтрак» [2, ф. p-726, оп. 1, д. 5, л. 36]. В 1934 г. Повенецкий дошкольный детдом по отчётам не получал несколько месяцев молоко, продукты отпускались с перебоями, на питание ребёнка расходовалось 20 руб. в месяц [2, ф. р-726, оп. 2, д. 9, л. 18]. В Шуерецкий детдом Кемского района в 1934 г. совершенно не поступали растительное масло и сахар, молоком учреждение снабжалось по 4-5л в день на 26 чел. (150-200 мл на одного ребёнка), «мясо, масло живое есть, крупу и макароны получали свободно, хлеба было достаточно, картофель и капуста - ни на один месяц, крупа (пшено и перловая) - в достатке» [2, ф. p-726, оп. 1, д. 31, л. 2]. В 1935 г. снабжение Космозерского детдома было удовлетворительным по части продуктов, обеспечение хлебом было поставлено плохо, три квартала года не получали чай, целый год — растительное масло, три месяца — сахар [2, ф. p-726, оп. 1, д. 31, л. 2]. 
Часто отсутствие нормированного питания было связано в Карелии с недопоставками продовольствия и невозможностью его организации. Питание детей могло быть однообразным в течение недели из-за частой нехватки на местном рынке отдельных продуктов. Например, воспитанники Шальского детдома питались исключительно одной рыбой, молока и жиров практически не получали [2, ф. p-2, оп. 1, д. 940, л. 10]. Работники детских учреждений не могли решить данный вопрос, и сами зачастую питались из «общего котла» с детьми.

Детские учреждения не могли позволить себе приобрести необходимые продукты из-за отсутствия или сокращения денежных средств. В 1934 г. Деткомиссия при ВЦИК, проводя обследование работы детдомов в Карелии, зафиксировала уменьшение количества отпускаемых денежных средств на питание детей: вместо установленных правительством РСФСР 400 руб. в год на воспитанника тратилось 360 руб. [1, ф. p-5207, оп. 1, д. 797, л. 1]. Также наблюдалось резкое понижение ассигнований на продовольствие детей по отдельным районам: в Пудожском детдоме - до 184 руб., в Повенецком детдоме - до 240 руб. [1, ф. p-5207, оп. 1, д. 797, л. 6], что было результатом отсутствия финансирования и экономии республиканских властей.

В первой половине 1930-х гг. продолжало существовать подсобное хозяйство при детдомах, на развитие которого стали отпускаться средства из фондов Деткомиссии при КарЦИК. В этот период в подсобном хозяйстве некоторых детдомов в Карелии держали следующий домашний скот: куры, гуси, утки, кролики, свиньи, лошади. Картофель, морковь, лук, репа, свёкла, брюква, полученные с огорода, дополняли рацион питания детей. Например, в 1932 г. Повенецким детдомом для трудновоспитуемых было получено от своего огорода 1785 к2 картофеля [2, ф. р-726, оп. 2, д. 2, л. 3]. В хозяйстве дошкольного детдома в Повенце в 1934 г. было 10 кур, 5 кроликов, огород на $4 m$ картофеля [1, ф. p5207, оп. 1, д. 797, л. 55]. Подсобное хозяйство Космозерского детдома состояло из лошади, быка, телёнка, 4 коров, 2 свиней, а также посева с огородом на 2 га и покоса на 20 га [2, ф. p-726, оп. 1, д. 32 , л. 3]. В том же году огород карело-финского детского дома в Петрозаводске дал $4 m$ картофеля, 300 кг овощей, скошенного сена с 8 га лугов [1, ф. p-5207, оп. 1, д. 797, л. 40].

Одна из главных задач подсобных хозяйств при детдомах заключалась в улучшении питания воспитанников. Их развитие в последующие годы отчасти было связано с Постановлением Совнаркома СССР, ЦК ВКП(б) от 31 мая 1935 г. «О ликвидации детской беспризорности и безнадзорности». В разделе об улучшении состояния детдомов и трудовых колоний говорилось о необходимости «отвести всем детдомам, в первую очередь, в сельских местностях и небольших городах, земельные участки для обработки их самими воспитанниками (разведение огородов, садов, ягодников, посевы продовольственных культур) и обеспечить развитие животноводческого хозяйства» [28].

На протяжении изучаемого периода нехватка продуктов питания была одной из главных причин побегов воспитанников из детских учреждений. При побеге дети старались унести с собой украденные продукты, обмундирование, а затем продать это на местных рынках. Например, в 1922 г. Комиссия по делам несовершеннолетних рассматривала вопрос о побеге двух воспитанников из приёмника Петрозаводска и краже «казёенных костюмов», проданных местному населению [2, ф. p-282, оп. 2, д. 57, л. 17]. По воспоминаниям воспитательниц Палеостровского детдома в 1934 г., учреждение было «скопищем хулиганов», воровавших в учреждении. После чего другие воспитанники оставались «без огурцов, капусты, клюквы на зиму» [2, ф. р-393, оп. 2, д. 5, л. 34].

В 1920-1930-х гг. врачи изучали вопрос улучшения здорового питания детей. Не только продовольственный паёк воспитанника детдома был подчинён определённым нормам, но и само меню, и режим питания.

Врач Н. К. Игнатов в своём труде излагал основные требования к питанию ребёнка в качественном и количественном отношении, определяя, сколько пищи требовалось в течение суток для правильного питания детей разного возраста. Пищевой паёк необходимо было правильно распределять на день. Врачи считали, что наиболее целесообразно отдельные приёмы пищи разделять таким образом, чтобы дети получали её приблизительно через каждые 3-4 часа [14, с. 188].

Н. К. Игнатов рекомендовал схему следующего расписания приёма пищи: «07.00 - завтрак № $1-15 \%$ суточного пайка, $10.00-$ завтрак № $2-10 \%, 13.00-$ обед $-35 \%, 17.00-$ полдник $-15 \%, 20.00-$ ужин - $25 \%$ \% [14, с. 188]. Для детей старшего возраста считались достаточными в течение дня четыре приёма пищи, поэтому разрешалось исключить второй завтрак или полдник.

Проф. Л. Лангштейн считал, что питание детей по расписанию должно соответствовать питанию взрослых: обедать между 12 и 14 часами, перед наступлением вечернего времени суток приём пищи необязателен, ужинать за полчаса до сна [19, с. 54]. 
Инструкторы питания Института охраны материнства и младенчества, Отдела охраны здоровья детей и подростков Наркомздрава РСФСР составляли книги с кулинарными рецептами для детей. В 1926 г. предлагалось следующее меню завтраков, обедов и ужинов для воспитанников детдома в течение недели (табл. 3) [13, с. 32-38]:

Таблица 3

Меню для воспитанников детдома, 1926 г.

\begin{tabular}{|c|c|c|c|c|c|c|c|}
\hline & $\begin{array}{c}\text { Первый } \\
\text { день }\end{array}$ & $\begin{array}{c}\text { Второй } \\
\text { день }\end{array}$ & $\begin{array}{l}\text { Третий } \\
\text { день }\end{array}$ & $\begin{array}{c}\text { Четвер- } \\
\text { тый } \\
\text { день }\end{array}$ & $\begin{array}{c}\text { Пятый } \\
\text { день }\end{array}$ & $\begin{array}{c}\text { Шестой } \\
\text { день }\end{array}$ & $\begin{array}{c}\text { Седьмой } \\
\text { день }\end{array}$ \\
\hline Завтрак & $\begin{array}{l}\text { Чай, сахар, } \\
\text { хлеб, масло }\end{array}$ & $\begin{array}{l}\text { Чай, сахар, } \\
\text { хлеб, масло }\end{array}$ & $\begin{array}{l}\text { Чай, сахар, } \\
\text { хлеб, масло }\end{array}$ & $\begin{array}{l}\text { Чай, сахар, } \\
\text { хлеб, масло }\end{array}$ & $\begin{array}{l}\text { Чай, сахар, } \\
\text { хлеб, масло }\end{array}$ & $\begin{array}{l}\text { Чай, сахар, } \\
\text { хлеб, масло }\end{array}$ & $\begin{array}{l}\text { Чай, сахар, } \\
\text { хлеб, масло }\end{array}$ \\
\hline Обед & $\begin{array}{l}\text { Суп карто- } \\
\text { фельный } \\
\text { с грибами, } \\
\text { поджарен- } \\
\text { ным луком } \\
\text { и маслом; } \\
\text { котлеты } \\
\text { мясные } \\
\text { с перловой } \\
\text { кашей }\end{array}$ & $\begin{array}{l}\text { Суп мясной } \\
\text { с лапшой, } \\
\text { поджарен- } \\
\text { ной с луком; } \\
\text { картофель- } \\
\text { ные котлеты } \\
\text { с грибным } \\
\text { соусом }\end{array}$ & $\begin{array}{l}\text { Суп мясной } \\
\text { с ячневой } \\
\text { крупой, кар- } \\
\text { тофелем и } \\
\text { луком; рыба } \\
\text { (судак) раз- } \\
\text { варная с } \\
\text { томатом и } \\
\text { соусом и } \\
\text { разварным } \\
\text { картофелем }\end{array}$ & $\begin{array}{l}\text { Борщ с } \\
\text { мясом и } \\
\text { томатом; } \\
\text { пироги с } \\
\text { рисом, } \\
\text { яйцами и } \\
\text { луком }\end{array}$ & $\begin{array}{l}\text { Суп вегета- } \\
\text { рианский с } \\
\text { ячневой кру- } \\
\text { пой, карто- } \\
\text { фелем, гри- } \\
\text { бами, мас- } \\
\text { лом, смета- } \\
\text { ной; жареная } \\
\text { печёнка со } \\
\text { сметаной и } \\
\text { картофель- } \\
\text { ным пюре }\end{array}$ & $\begin{array}{l}\text { Суп горохо- } \\
\text { вый с мясом, } \\
\text { солянка из } \\
\text { капусты, } \\
\text { рыбы с то- } \\
\text { матом }\end{array}$ & $\begin{array}{l}\text { Ленивые } \\
\text { щи } \\
\text { с мясом и } \\
\text { картофе- } \\
\text { лем; жаре- } \\
\text { ная рыба } \\
\text { (судак) с } \\
\text { картофе- } \\
\text { лем }\end{array}$ \\
\hline Ужин & $\begin{array}{l}\text { Макароны } \\
\text { с творогом } \\
\text { и маслом }\end{array}$ & $\begin{array}{l}\text { Рисовая ка- } \\
\text { ша с маслом }\end{array}$ & $\begin{array}{l}\text { Каша } \\
\text { пшённая с } \\
\text { компотом }\end{array}$ & $\begin{array}{l}\text { Гречневая } \\
\text { каша с } \\
\text { молоком }\end{array}$ & $\begin{array}{l}\text { Запечённые } \\
\text { макароны с } \\
\text { маслом }\end{array}$ & $\begin{array}{l}\text { Картофель- } \\
\text { ная запекан- } \\
\text { ка с яйцами }\end{array}$ & $\begin{array}{l}\text { Гречневая } \\
\text { каша с мо- } \\
\text { локом }\end{array}$ \\
\hline $\begin{array}{l}\text { Второй } \\
\text { ужин }\end{array}$ & $\begin{array}{l}\text { Хлеб, } \\
\text { молоко }\end{array}$ & $\begin{array}{l}\text { Хлеб, моло- } \\
\text { ко }\end{array}$ & $\begin{array}{l}\text { Хлеб, мо- } \\
\text { локо }\end{array}$ & $\begin{array}{l}\text { Чай, са- } \\
\text { хар, хлеб, } \\
\text { масло }\end{array}$ & $\begin{array}{l}\text { Хлеб, моло- } \\
\text { ко }\end{array}$ & $\begin{array}{l}\text { Хлеб, моло- } \\
\text { ко }\end{array}$ & $\begin{array}{l}\text { Чай, сахар, } \\
\text { хлеб, масло }\end{array}$ \\
\hline
\end{tabular}

Как видим, утренние и вечерние приёмы пищи были однообразны, обеды состояли из двух блюд, одним из которых обязательно был суп. Ужин обычно представлен кашей или макаронами.

М. Г. Данилевич предлагал следующее распределение пищи в течение суток: первая еда: один стакан молока или чай, кофе с молоком и хлеб с маслом, сыром, повидлом; вторая еда: фрукты или фруктовые соки, или овощные пюре, бутерброды с паштетом и проч., хлеб (с маслом); третья еда: первое блюдо - разнообразные супы, второе блюдо - рыбное или мясное с овощами, салатом, третье блюдо - компоты, кисели, фрукты; четвёртая еда: приблизительно та же, что и первая; пятая еда: ужин - одно блюдо (каша, картофель, творог, молоко и пр.) [9, с. 24].

В 1928 г. доктора разработали «правильное меню» (как это значилось в документе) для детей дошкольного возраста, включавшее следующие блюда в течение недели (табл. 4) [12, с. 24]:

Подготовленная врачами в 1920-х гг. теоретическая база улучшения питания ребёнка не получила полного распространения в детдомах Карелии. Сотрудники в учреждениях придерживались определённого распределения пищи в течение дня, но разнообразить ежедневные блюда воспитанников не могли. Например, в Кемском детдоме распорядок питания и меню в 1926 г. был таким: в $08.00-$ чай с хлебом и сливочным маслом, в 14.00 - обед из двух блюд, в 17.00 - чай с булкой, в $21.30-$ на ужин одно блюдо $[2$, ф. p-630, оп. 1, д. 197, д. 2]. Заведующий Кемского детдома в отчётах фиксировал, что меню каждый день менялось с учётом пожелания детей $[2, \phi$. p-630, оп. 1, д. 197, л. 2].

В отчётах первой половины 1930-х гг. велось более подробное описание питания детей за день, из него видно некоторое улучшение суточного пайка воспитанников. Например, в первом детдоме Петрозаводска в 1933 г. принятие пищи было следующим: «утром чай с хлебом и маслом, обеды бывали из двух блюд: суп мясной, овощной или рыбный, каша, картошка или макароны. Вечером каша или суп» [2, ф. p-726, оп. 1, д. 5, л. 36]. Режим питания в Повенецком дошкольном детдоме не сильно отличался от описанного выше: «утром - чай с сахаром, очень редко с маслом, обед — два блюда (первое редко бывало мясное или рыбное), чай с хлебом, ужин - макароны с сахаром или каша» [2, ф. р-726, оп. 2 , д. 9, л. 18$]$. 
Меню для детей в возрасте от 2 до 5 лет

Таблица 4

\begin{tabular}{|c|c|c|c|c|c|c|c|}
\hline & Воскресенье & Понедельник & Вторник & Среда & Четверг & Пятница & Суббота \\
\hline Завтрак & $\begin{array}{l}\text { Молоко } \\
\text { с сахаром, } \\
\text { чёрный хлеб } \\
\text { с маслом } \\
\text { и сыром } \\
\text { голландским }\end{array}$ & $\begin{array}{l}\text { Кофе, хлеб с } \\
\text { маслом, яйцо }\end{array}$ & $\begin{array}{l}\text { Чай с мо- } \\
\text { локом, } \\
\text { хлеб с } \\
\text { маслом, } \\
\text { холодная } \\
\text { телятина }\end{array}$ & $\begin{array}{l}\text { Какао, } \\
\text { хлеб с } \\
\text { маслом, } \\
\text { творог с } \\
\text { холод- } \\
\text { ной сме- } \\
\text { таной }\end{array}$ & $\begin{array}{l}\text { Молоко с } \\
\text { сахаром, } \\
\text { яичница с } \\
\text { хлебом, с } \\
\text { маслом }\end{array}$ & $\begin{array}{l}\text { Кофе, } \\
\text { хлеб с } \\
\text { рубленой } \\
\text { печёнкой }\end{array}$ & $\begin{array}{l}\text { Чай с мо- } \\
\text { локом, } \\
\text { хлеб с } \\
\text { маслом, } \\
\text { варенец, } \\
\text { нежирная } \\
\text { ветчина }\end{array}$ \\
\hline Обед & $\begin{array}{l}\text { Перловый суп, } \\
\text { котлеты говя- } \\
\text { жьи с морков- } \\
\text { ным пюре, } \\
\text { компот из су- } \\
\text { хих фруктов }\end{array}$ & $\begin{array}{l}\text { Борщ со смета- } \\
\text { ной, рисовый } \\
\text { пудинг, клюк- } \\
\text { венный кисель }\end{array}$ & $\begin{array}{l}\text { Лапша } \\
\text { молочная, } \\
\text { мозги жа- } \\
\text { реные с } \\
\text { жареным } \\
\text { картофе- } \\
\text { лем, мо- } \\
\text { лочный } \\
\text { кисель }\end{array}$ & $\begin{array}{l}\text { Щи ле- } \\
\text { нивые, } \\
\text { рыбные } \\
\text { котлеты } \\
\text { с отвар- } \\
\text { ным } \\
\text { карто- } \\
\text { фелем, } \\
\text { компот } \\
\text { из урюка }\end{array}$ & $\begin{array}{l}\text { Суп кар- } \\
\text { тофель- } \\
\text { ный, го- } \\
\text { лубцы с } \\
\text { мясом и } \\
\text { гречневой } \\
\text { кашей, } \\
\text { фрукто- } \\
\text { вый мусс }\end{array}$ & $\begin{array}{l}\text { Суп пюре } \\
\text { из тома- } \\
\text { тов со } \\
\text { сметаной, } \\
\text { макароны } \\
\text { с маслом, } \\
\text { кисель из } \\
\text { вишни }\end{array}$ & $\begin{array}{l}\text { Бульон с } \\
\text { манной } \\
\text { крупой, } \\
\text { печёнка в } \\
\text { сметане с } \\
\text { карто- } \\
\text { фельным } \\
\text { пюре, } \\
\text { печёное } \\
\text { яблоко }\end{array}$ \\
\hline Полдник & $\begin{array}{l}\text { Чай с молоком, } \\
\text { пирог с ябло- } \\
\text { ком }\end{array}$ & $\begin{array}{l}\text { Кофе, хлеб с } \\
\text { маслом, фрукты }\end{array}$ & $\begin{array}{l}\text { Молоко с } \\
\text { сахаром, } \\
\text { крендели, } \\
\text { фрукты }\end{array}$ & $\begin{array}{l}\text { Чай с } \\
\text { моло- } \\
\text { ком, } \\
\text { сдобный } \\
\text { хлеб, } \\
\text { фрукты }\end{array}$ & $\begin{array}{l}\text { Кофе с } \\
\text { молоком, } \\
\text { печенье } \\
\text { (Альберт), } \\
\text { фрукты }\end{array}$ & $\begin{array}{l}\text { Молоко, } \\
\text { кулебяка, } \\
\text { фрукты }\end{array}$ & $\begin{array}{l}\text { Какао, } \\
\text { ватрушки } \\
\text { с творо- } \\
\text { гом, } \\
\text { фрукты }\end{array}$ \\
\hline Ужин & $\begin{array}{l}\text { Котлеты кар- } \\
\text { тофельные с } \\
\text { грибной под- } \\
\text { ливкой, печё- } \\
\text { ное яблоко }\end{array}$ & $\begin{array}{l}\text { Творожники со } \\
\text { сладким соусом, } \\
\text { компот из сухих } \\
\text { фруктов }\end{array}$ & $\begin{array}{l}\text { Крупеник } \\
\text { или омлет, } \\
\text { клюквен- } \\
\text { ный ки- } \\
\text { сель } \\
\end{array}$ & $\begin{array}{l}\text { Пудинг } \\
\text { рисовый, } \\
\text { яблочный } \\
\text { мусс }\end{array}$ & $\begin{array}{l}\text { Запеканка } \\
\text { из ово- } \\
\text { щей, ком- } \\
\text { пот из } \\
\text { урюка }\end{array}$ & $\begin{array}{l}\text { Яичница, } \\
\text { молочный } \\
\text { кисель }\end{array}$ & $\begin{array}{l}\text { Шарлот- } \\
\text { ка, кисель } \\
\text { из вишни }\end{array}$ \\
\hline
\end{tabular}

Таким образом, среди множества проблем, с которыми сталкивались в детдомах, проблема обеспечения продовольствием воспитанников была основной на протяжении 1920-х - первой половины 1930-х гг. как на территории Карелии, так и в целом по стране. Врачи и инструкторы Наркомпроса и Наркомздрава РСФСР занимались различными направлениями этого вопроса: разработкой норм суточного пищевого пайка, определением необходимого количества полезных элементов в питании, составлением правильного меню для детей и др. Обращение к нормативам детского питания и отчётности детдомов и Наркомпроса АКССР позволило увидеть существовавший разрыв между утверждённым и реальным обеспечением учреждений.

Ситуация с продовольственным обеспечением детских учреждений менялась в течение изучаемого периода. Для Карелии можно выделить следующие этапы состояния питания воспитанников детдомов: первая половина 1920-х гг. - неудовлетворительное положение продовольственного вопроса, отсутствие единых общегосударственных норм питания детей, несовпадение нормативов детского пищевого пайка на местах с разработанными нормами Отдела охраны здоровья Наркомпроса РСФСР и рекомендациями врачей; вторая половина 1920-х гг. - постепенное улучшение питания в связи с появлением подсобных хозяйств детских учреждений; первая половина 1930-х гг. - корректировка нормативов питания по стране и, в частности, в Карелии; изменение состояния продовольственного обеспечения детей, выявление проблемы финансирования питания воспитанников детдомов, улучшение показателей подсобных хозяйств детдомов за счёт выделения дополнительных средств Деткомиссией при КарЦИК.

В исследуемый период сохранялись следующие проблемы и трудности в обеспечении питанием воспитанников детдомов: некачественные продукты, нехватка денежных средств на покупку продовольствия, отсутствие продуктов на рынке, плохая транспортировка продовольствия, несоответствие детского пайка общим нормам и рекомендациям врачей. Полного решения этих проблем не было достигнуто в 1920-х — первой половине 1930-х гг., но наблюдалось определённое улучшение в обеспеченности продовольствием воспитанников детдомов. 


\section{СПИСОК ИСТОЧНИКОВ И ЛИТЕРАТУРЫ}

1. Государственный архив Российской Федерации (ГА РФ).

2. Национальный архив Республики Карелия (НА РК).

3. Абрахманов Р. Р. Детские дома и приюты на территории Башкирии в 1917-1928 годах // Вестн. Челяб. гос. ун-та. 2009. № 41. С. 41-44.

4. Афанасова E. Н. Детские дома на территории Якутской АССР в 1920-е гг. // Гуманитарные исследования в Восточной Сибири и на Дальнем Востоке. 2015. № 1. С. 78-81.

5. Войнаровская Ю. В. Борьба с беспризорностью в малых городах Поволжья в 1920-1930-х гг. (на примере г. Сызрыни и г. Елабуги) // Вестн. СамГУ. 2001. № 1. С. 18-22.

6. Гиндес Е. Я. Таблицы питания детей до 5-летнего возраста. Баку: [б. и.], 1933. 56 с.

7. Гуткин А. Я. Питание детей в школе: (Организация и постановка питания). Л.: Ленинградский институт ОЗД и П, 1934. 53 с.

8. Данилевич М. Г. Вопросы питания детей. Л.: Санпросвет Ленингр. губздравотдела, 1925. 40 с.

9. Данилевич М. Г. Питание ребёнка. Л.: Изд-во «Ленинградская правда», 1928. 32 с.

10. Доброхотова А. И. Практическое пособие по питанию детей раннего возраста. М., Л.: Медгиз, 1933.78 с.

11. Дьяков Н. Н. Питание детей и голодные отёки у них. Пермь: Тип. Пермполиграфтреста, 1928. 9 с.

12. Женский журнал. 1928. Июль. № 7.

13. Здание школы, питание, одежда, режим труда и отдыха: Нормы, утв. Отд. охраны здоровья детей и подростков Нар. ком. здравоохранения. М.: Жизнь и знание, 1926. 78 с.

14. Игнатов H. K. Питание детей всех возрастов в связи с применением суррогатов и заменою одних продуктов другим. М.: [б. и.], 1922. 120 с.

15. Исраэлян Л. Г. Основы питания детей. Тифлис: Шрома, 1928. 86 с.

16. Карасева А. А. Финансирование и материальное снабжение детских домов в РСФСР в 1930-е гг. // Наука и школа. 2012. № 3. С. 175-179.

17. Киселёва В. Б. Детская кухня: приготовление пищи для детей от 6 месяцев до 3 лет: 323 рецепт. Л.: Прибой, $1928.151 \mathrm{c}$.

18. Козульчук T. В., Перова М. А. Сельские школы и детские дома Курганского округа: бытовые реалии 1920-х гг. // Аграрный вестник Урала. 2014. № 7. С. 66-73.

19. Лангштейн Л. Ребёнок дошкольного и школьного возраста: Его питание и уход за ним: Краткое руководство для родителей и воспитателей. Харьков: Научная мысль, 1929. 72 с.

20. Лупаренко C. Е. Детские городки в системе работы с беспризорными детьми в СССР (1920-1930 гг.) // Вестн. Оренбург. гос. пед. ун-та. 2014. № 1. С. 183-190.

21. Метелькова E. А. Детские дома в конце 1920-х — начале 1930-х гг. (на примере детского городка им. Луначарского и детской колонии им. Крупской г. Ярославля) // Ярославский пед. вестн. 2013. № 3. С. $249-253$.

22. Нормы питания детей дошкольного возраста: Эксперимент. Исследования / под ред. В. О. Мочана. Л.: Биомедгиз. Ленингр.отд-ние, 1935. 71 с.

23. Питание детей в яслях. М.: Музей-выставка ОММ Мособлздравотдела, 1935. 24 с.

24. Питание здорового и больного человека: Руководство для больниц, санаториев, домов отдыха, учреждений общественного питания, детских учреждений и санитарных врачей / под ред. А. Н. Сысина, Э. М. Бархана. М.: Гос. мед. изд-во, 1929. 290 с.

25. Попова А. В. Современное учение о питании малолетних детей. М.; Л.: Гос. мед. изд-во, 1929. 230 с.

26. Рябинина Н. В. Детская беспризорность и преступность в 1920-е годы (по материалам губерний Верхнего Поволжья): учеб. пособие. Ярославль: Изд-во Ярославского гос. ун-та, 1999. 58 с.

27. Смирнова T. М. Дети страны Советов: от государственной политики к реалиям повседневной жизни. $1917-$ 1949 гг. М., СПб.: Ин-т российской истории РАН; Центр гуманитарных инициатив, 2015. 384 с.

28. Собрание законов и распоряжений Рабоче-крестьянского правительства CCCP за 1934 г. № 56 . URL: http://istmat.info/node/42490

29. Соловиева T. A. Повседневная жизнь воспитанников детских домов советского провинциального города в 1920-1930-е годы // Изв. Саратов. ун-та. Сер. История. Междунар. отн-я. 2013. Т. 13. Вып. 2. С. $42-45$.

30. Typ A. Ф. Рациональное питание детей в возрасте от 1 года до 4 лет в условиях сельской обстановки. М.: Гос. мед. изд-во, $1932.16 \mathrm{c.}$

31. Чумаевская О. А. Практическое руководство для питания детей от 1 до 4 лет. Свердловск: Сверд. обл. науч.практич. ин-та охраны материнства и младенчества, 1935. 112 с.

Поступила в редакцию 09.01.2019

Чебаковская Александра Вячеславовна, и. о. младшего научного сотрудника

ФГБУН ФИЦ «Карельский научный центр РАН», Институт языка, литературы и истории КарНЦ РАН

185910, Россия, г. Петрозаводск, ул. Пушкинская, 11

E-mail: chebakovskaja@yandex.ru 


\title{
A.V. Chebakovskaya \\ FOOD RATIONS FOR CHILDREN IN ORPHANAGES OF KARELIA IN THE 1920s AND THE FIRST HALF OF THE 1930s
}

\author{
DOI: $10.35634 / 2412-9534-2020-30-1-153-164$
}

The article considers the issue of food provision to children in orphanages of Karelia in the 1920s and the first half of the 1930s. The problem of child nutrition was addressed in the official documents of the People's Commissariat for Education of the Russian Soviet Federative Socialistic Republic as well as in the Soviet doctors' works of recommendatory character. Instructors and doctors of the People's Commissariat for Education and the People's Commissariat for Health dealt with various nutrition issues for children in orphanages. They worked on daily food rations and healthy menus for children, measured the amount of useful nutrients needed, etc. The purpose of this article is to compare standards and the actual situation with rations for children in orphanages in the 1920s and the first half of the 1930s. The article was compiled using materials and documents provided by the State Archive of the Russian Federation and the National Archive of the Republic of Karelia, which helped to see not only the food standards approved by the Department of Welfare of the People's Commissariat for Education, but also the actual provision of food to the child care facilities. Various issues of food provision to children in orphanages which were not entirely resolved stood out during the period of study.

Keywords: child welfare, orphanage, child nutrition, food ration, Karelia.

\section{REFERENCES}

1. Gosudarstvennyy arkhiv Rossiyskoy Federatsii [State Archive of the Russian Federation]. (in Russian, unpublished).

2. Natsionalnyy arkhiv Respubliki Kareliya [Republic of Karelia National Archive]. (in Russian, unpublished).

3. Abrahmanov R. R. Detskie doma i priyuty na territorii Bashkirii v 1917-1928 godah [Orphanages in the Republic of Bashkortostan in 1917-1928]. Vestnik Chelyabinskogo gosudarstvennogo universiteta [Bulletin of Chelyabinsk State University], 2009, no. 41, pp. 41-44. (In Russian).

4. Afanasova E. N. Detskie doma na territorii Yakutskoj ASSR v 1920-e gg. [Orphanages in the Yakut Autonomous Soviet Socialist Republic in the 1920th]. Gumanitarnye issledovaniya v Vostochnoj Sibiri i na Dal'nem Vostoke [Humanities Research in the Russian Far East], 2015, no. 1, pp. 78-81. (In Russian).

5. Voynarovskaya Yu. V. Borba s besprizornostyu v malykh gorodakh Povolzhia v 1920-1930-kh gg. (na primere g. Syzryni i g. Elabugi) [Combating Child Homelessness in the Volga Region towns in the 1920-1930s (using the examples of Syzran and Elabuga)]. Vestnik SamGU [Bulletin of Samara State University], 2001, no. 1, pp. 18-22. (In Russian).

6. Gindes E. Ya. Tablitsy pitaniya detey do 5-letnego vozrasta [Food Summary Tables for children under 5 years]. Baku, [n. a.], 1933, 56 p. (In Russian).

7. Gutkin A. Ya. Pitaniye detey v shkole [Meals for Children at Schools]. Leningrad, Leningrad Institute of child and adolescent health Press, 1934, 53 p. (In Russian).

8. Danilevich M. G. Voprosy pitaniya detey [Child Nutrition issues]. Leningrad, Sanprosvet Leningr. Gubzdravotdela Publ., 1925, 40 p. (In Russian).

9. Danilevich M. G. Pitaniye rebenka [Child Nutrition]. Leningrad, Leningrad truth Press, 1928, 32 p. (In Russian).

10. Dobrokhotova A. I. Prakticheskoye posobiye po pitaniyu detey rannego vozrasta [Handbook for Young Children Nutrition]. Moscow, Leningrad, “Medgiz” Publ., 1933, 78 p. (In Russian).

11. Diakov N. N. Pitaniye detey i golodnyye oteki u nikh [Child Nutrition and Hunger Edema in Children]. Perm, "Permpoligraftresta" Publ., 1928, 9 p. (In Russian).

12. Zhenskiy zhurnal [Women's periodical], 1928, July, no. 7. (In Russian).

13. Zdaniye shkoly, pitaniye, odezhda, rezhim truda i otdykha: Normy. utv. Otd. okhrany zdorovia detey i podrostkov Nar. kom. Zdravookhraneniya [School building, food, clothing, work-rest regime: Standards, approved by the Department of Child and Teenage Health of the People's Commissariat for Health]. Moscow, "Nauka i zhizn" Publ., 1926, 78 p. (In Russian).

14. Ignatov N. K. Pitaniye detey vsekh vozrastov v svyazi s primeneniyem surrogatov i zamenoyu odnikh produktov drugim [Nutrition for children of all ages in connection with products' replacement and surrogates consumption]. Moscow, 1922, 120 p. (In Russian).

15. Israelyan L. G. Osnovy pitaniya detey [Child Nutrition Basics]. Tiflis, "Shroma” Publ., 1928, 86 s. (In Russian).

16. Karaseva A. A. Finansirovaniye i materialnoye snabzheniye detskikh domov v RSFSR v 1930-e gg. [Russian Soviet Federative Socialist Republic Orphanages Financing in the 1930s]. Nauka i shkola [Science and school], 2012 , no. 3, pp. 175-179. (In Russian).

17. Kiseleva $V$. B. Detskaya kukhnya: Prigotovleniye pishchi dlya detey ot 6 mesyatsev do 3 let: 323 retsept [Child Nutrition: Cooking for Children aged 6 months to 3 years: 323 recipes]. Leningrad, "Priboy" Publ., 1928, 151 p. (In Russian). 
18. Kozulchuk T. V. Perova M.A. Selskiye shkoly i detskiye doma Kurganskogo okruga: bytovyye realii 1920-kh gg. [Countryside Schools and Orphanages of the Kurgan Region: Realities of the 1920s]. Agrarnyy vestnik Urala [Agrarian Bulletin of the Urals], 2014, no. 7, pp. 66-73. (In Russian).

19. Langshteyn L. Rebenok doshkolnogo i shkolnogo vozrasta: Ego pitaniye i ukhod za nim: Kratkoye rukovodstvo dlya roditeley i vospitateley [Children of Pre-School and School Age: Nutrition and Child Care: A brief guide for parents and teachers], Kharkov, "Nauchnaya mysl" Publ., 1929, 72 p. (In Russian).

20. Luparenko S. E. Detskiye gorodki v sisteme raboty s besprizornymi detmi v SSSR (1920-1930 gg.) [Children Communities as a part of Street Children Programs in USSR. (1920-1930]. Vestnik Orenburgskogo gosudarstvennogo pedagogicheskogo universiteta [Bulletin of Orenburg State Pedagogical University], 2014, no. 1, pp. 183-190. (In Russian).

21. Metelkova E. A. Detskiye doma v kontse 1920-kh - nachale 1930-kh gg. (na primere detskogo gorodka im. Lunacharskogo i detskoy kolonii im. Krupskoy g. Yaroslavlya) [Orphanages at the end of 1920s - at the beginning of 1930s (using the example of Lunacharsky Children Community and Krupskaya Children's Colony in Yaroslavl)]. Yaroslavskiy pedagogicheskiy vestnik [Yaroslavl Pedagogical Bulletin], 2013, no. 3, pp. 249-253. (In Russian).

22. Normy pitaniya detey doshkolnogo vozrasta: Eksperiment. Issledovaniya [Nutritional standards for children of preschool age: Experiment. Research]. Pod red. V. O. Mochana. Leningrad, "Biomedgiz" Publ., 1935, 71 p. (In Russian).

23. Pitaniye detey v yaslyakh [Nursery Menus], Moscow, Muzey-vystavka OMM Mosoblzdravotdela Publ., 1935,24 p. (In Russian).

24. Pitaniye zdorovogo i bolnogo cheloveka: Rukovodstvo dlya bolnits. sanatoriyev. domov otdykha. uchrezhdeniy obshchestvennogo pitaniya. detskikh uchrezhdeniy i sanitarnykh vrachey [Healthy and sick men's menu: A guide for hospitals, sanatoriums, holiday houses, catering establishments, child-care facilities and medical officers]. Pod red. A. N. Sysina i E. M. Barkhana. Moscow, State Medical Press, 1929, 290 p. (In Russian).

25. Popova A. V. Sovremennoye ucheniye o pitanii maloletnikh detey [Modern Studies on Nutrition for Young Children]. Moscow, Leningrad, State Medical Press, 1929, 230 p. (In Russian).

26. Ryabinina N. V. Detskaya besprizornost i prestupnost v 1920-e gody (po materialam guberniy Verkhnego Povolzhia): uchebnoye posobiye [Handbook: Child Homelessness and Juvenile Delinquency in the 1920s (on evidence from the Upper Volga Region provinces)]. Yaroslavl, Yaroslavl State University Press, 1999, 58 p. (In Russian).

27. Smirnova T. M. Deti strany Sovetov: Ot gosudarstvennoy politiki k realiyam povsednevnoy zhizni. 1917-1940 gg. [Children of the country of Soviets: From public policy to the realities of everyday life. 1917-1940], Moscow, Saint Petersburg, Ed. of the Institute of Russian History of Russian Academy of Sciences, 2015, 384 p. (In Russian).

28. Sobraniye zakonov i rasporyazheniy Raboche-krestianskogo pravitelstva SSSR za $1934 \mathrm{~g}$. [Collection of laws and decrees of the Workers' and Peasants' government of the USSR in 1934], no. 56, URL: http://istmat.info/node/42490 (accessed 20.10.2018). (In Russian).

29. Soloviyeva T. A. Povsednevnaya zhizn vospitannikov detskikh domov sovetskogo provintsialnogo goroda v 1920 1930-e gody [Everyday life of Orphanage Children in a provincial town in the 1920-1930s]. Izvestiya Saratovskogo universiteta. Seriya Istoriya. Mezhdunarodnyye otnosheniya [News of Saratov University. Series History. International Relations.], 2013, vol. 13, issue 2, pp. 42-45. (In Russian).

30. Tur A. F. Ratsionalnoye pitaniye detey v vozraste ot 1 goda do 4 let v usloviyakh selskoy obstanovki [Rational Nutrition of Children Aged 1-4 in the countryside]. Moscow, State Medical Press, 1932, 16 p. (In Russian).

31. Chumayevskaya O. A. Prakticheskoye rukovodstvo dlya pitaniya detey ot 1 do 4 let [Handbook of Nutrition of Children Aged 1-4]. Sverdlovsk, Ed. of the Sverdlovsk Regional Scientific and Practical Institute of Maternity and Infancy Protection, 1935, 112 p. (In Russian).

Received 09.01.2019

Chebakovskaja A. V., Acting Junior Research Officer

Institute of Linguistics, Literature and History of Karelian Research Centre of the Russian Academy of Sciences Pushkinskaya st., 11, Petrozavodsk, Russia, 185910

E-mail: chebakovskaja@yandex.ru 